\title{
Evaluation of an Occupational Health and Safety Management System in Universitas Indonesia
}

\author{
* $1^{\text {st }}$ Aditya Nugroho \\ Department of Civil Engineering \\ Faculty of Engineering, Universitas \\ Indonesia \\ Depok, Indonesia \\ Aditya_nugroho@outlook.com \\ $3^{\text {rd }}$ Yusuf Latief \\ Department of Civil Engineering \\ Faculty of Engineering, Universitas \\ Indonesia \\ Depok, Indonesia
}

\author{
$2^{\text {nd }}$ Ayu Herzanita \\ Department of Civil Engineering \\ Faculty of Engineering, Universitas \\ Indonesia \\ Depok, Indonesia \\ $4^{\text {th }}$ Leni Sagita \\ Department of Civil Engineering \\ Faculty of Engineering, Universitas \\ Indonesia \\ Depok, Indonesia
}

\begin{abstract}
The University is an institution of higher education and research that must be able to guarantee the safety of all interested parties in the university area to prevent accidents and occupational diseases, both in academic activities such as laboratory safety and other activities such as construction activities within the university area. This research was conducted to assess the implementation of Occupational Safety and Health Management System (OHSMS) at Universitas Indonesia, referring to Government Regulation of the Republic of Indonesia Number 50 of 2012 regarding the application of OHSMS and ISO 45001:2018 as international standards on OHSMS. The methodology used in this research uses interview and archive analysis with validation by experts and practitioner through a questionnaire based on those OHSMS standard and regulation. Universitas Indonesia has implemented OHSMS which consists of: (1) Policy, (2) Planning, (3) Operation, (4) Monitoring, and (5) Improvement. Furthermore, Universitas Indonesia has formed a specific unit tasked with developing and organizing OHS programs \& OHS procedures, including prevention and mitigation of work accident and diseases.
\end{abstract}

Keywords-Occupational Health and Safety, University, PP 50/2012, ISO 45001:2018

\section{INTRODUCTION}

The university is an institution of higher education and research aimed at the development of science. In a university area generally there are various kinds of supporting facilities for activities such as lecture buildings, administrative buildings, libraries, laboratories, canteens, transportation facilities, sports facilities, religious facilities, and so on. The university area is a place that is regularly visited by employees, lecturers, researchers, students, contractors, and various other guests. Universities must be able to guarantee the security and safety of all interested parties in the university area to prevent accidents [1-3]. Accidents that occur are generally caused by unsafe conditions and unsafe acts. Unsafe actions are defined as all human actions that can allow accidents to happen to themselves or others, while unsafe conditions are defined as one of the conditions of the work environment that can allow accidents to occur $[2,4]$.
There are various safety-related issues and health-related issues that need attention in the university area. The United States Chemical Safety Board (CSB) has conducted a review of 120 accidents that occurred in academic laboratories in 2001-2011 due to unsafe conditions and unsafe acts and concluded that safety practices in universities require great attention [5]. Construction activities that take place in the university area have a high risk for people who move around them so special supervision is needed [6,7]. Occupational diseases can occur in various activities in the university area, for example such as hearing loss due to noise, skeletal muscle disorders due to poor ergonomics, work stress, respiratory problems, including infectious diseases that are transmitted in the workplace [8]. At the Universitas Indonesia, a variety of incidents occur each year, which has been recorded and implemented the corrective actions needed. Incidents that occur include vehicle accidents (motorcycle, car, and bicycle), fallen trees, fires, occupational illness, person drowning, earthquakes, etc.

Occupational Health and Safety in Indonesia is regulated in Government Regulation of the Republic of Indonesia Number 50 of 2012. Certain organization that employs at least 100 people, or if it has a high potential hazard, should implement the Occupational Health and Safety Management System SMK3 for controlling risks related to work activities in order to create a safe, efficient and productive workplace [9]. In addition, International Organization for Standardization (ISO) has establishes ISO 45001:2018 as an international standard in the implementation of OHSMS [10].

Universitas Indonesia (UI) is one of the universities in Indonesia that has developed a Occupational Safety and Health Management System (OHSMS) in the university area. Universitas Indonesia has committed to implementing occupational safety and health that applies to UI students, lecturers, researchers, employees, contractors, guests, and various other visitors, to protect them from potential hazards and risks from activities carried out at the Universitas Indonesia. Moreover, Universitas Indonesia has formed a specific unit tasked with developing and organizing OHS programs \& OHS procedures. Assignments given to this unit 
including prevention and mitigation of work accident and diseases. This research was conducted to review the level of compliance of the OHSMS implementation at the Universitas Indonesia towards to Government Regulation of the Republic of Indonesia Number 50 of 2012 regarding the application of OHSMS and ISO 45001:2018 as international standards on OHSMS.

\section{LITERATURE REVIEW}

\section{A. Occupational Health and Safety Management System}

The definition of a system is a unit consisting of components or sub-systems that are orderly organized, interact with each other, interdependent, and cannot be separated (integrative) to realize a goal [11]. Subsequently, a management system is a set of interrelated or interacting elements which generally consist of Plan - Do - Check - Act cycle, or commonly referred to as Deming Wheel [12]. Hence, Occupational Health and Safety Management System (OHSMS) is a system used to manage and control safety, or is a management system specifically intended for safety [2].

Work safety is a condition that is safe or safe from suffering, damage or loss at work. Work safety is a form of protection that leads to physical and mental conditions and is related to efforts to prevent work accidents caused by various hazard factors, both originating from the work environment or the actions of the workers themselves [13,14]. Occupational health refers to the physical, mental and emotional stability in general of a worker. This is influenced by environmental factors both physically, chemically, or biologically. Healthy individuals are free from illnesses, injuries and mental and emotional problems that can interfere with normal human activity in general [15].

\section{B. OHSMS Regulation and Standard}

Regulation is a written rules made by a government and must be obeyed by all of its citizens. Indonesia has set regulations regarding the application of OHSMS, which is Government Regulation of the Republic of Indonesia Number 50 of 2012. Each country has its own OHSMS regulatory requirement, so The International Organization for Standardization establish ISO 45001:2018 as international standards on OHSMS. International standard is necessary because each organization has its unique conditions, characteristics, circumstances, strengths and weaknesses that could affect the outcomes of its OHSMS [16,17]. Both regulation and standard have similar requirement and structure related to OHSMS which consist of: (1) OHS Policy, (2) Planning, (3) Operation, (4) Monitoring, and (5) Continuous Improvement.

\section{RESEARCH METHOD}

The methodology used in this research uses interview and archive analysis with validation by experts and practitioner through a questionnaire based on those OHSMS standard and regulation. The first stage of this research is conducting interviews and gathering relevant documents related to OHSMS at the Universitas Indonesia. Interview are conducted to the "Unit Pelaksana Teknis Keselamatan, Kesehatan Kerja dan Lingkungan" or UPT K3L as a unit that in charge related to OHSMS implementation in Universitas
Indonesia. The second stage is the validating research questionnaire that consisting the requirements from both of the regulation and standard that are being used, through various OHS expert and practitioner. The third stage is the process of analysing the compliance between OHSMS implementation in Universitas Indonesia compared to the OHSMS regulation and standard.

\section{RESULT AND DisCUSSION}

\section{A. OHSMS Requirements and Compliance}

OHSMS requirements are taken from Government Regulation of the Republic of Indonesia No. 50/2012 and ISO 45001:2018. Overall, Universitas Indonesia has fulfill the requirements but there is several requirements that has been implemented but not yet documented. The results of the assessment are shown in Table 1.

\section{B. OHS Policy and Planning}

The Principal of Universitas Indonesia has established an OHS Policy in the form of a Principal Regulation, to protect all related parties and also protection of UI assets and environment from potential hazards associated with all types of activities that take place at UI. Furthermore, each of the faculty in Universitas Indonesia also establish its own OHS Policy and signed by the faculty dean as a prove of commitment to implement OHSMS in the faculty level. The Principal Regulation at Universitas Indonesia related to OHSMS consist of:

- Principal Regulation No. 01/2016 about Implementation of Occupational Health, Safety and Environment (OHSE) in Universitas Indonesia.

- Principal Regulation No. 02/2016 about Chemical Safety in Laboratory.

- Principal Regulation No. 03/2016 about Biosafety in Laboratory.

- Principal Regulation No. 04/2016 about OHSE for Construction Work.

- Principal Regulation No. 05/2016 about Radiation Safety.

- Principal Regulation No. 41/2017 about OHSE for Transportation in UI.

- Principal Regulation No. 57/2017 about OHSE for Canteen in UI

- Principal Regulation No. 29/2019 about OHSE for Goods and Services Providers in UI

ISO 45001:2018 stated an organization must take a holistic view and identify those specific internal and external factors, also the needs and expectations of various interested parties that have the ability to affect the outcomes of its OHSMS in any manner. Universitas Indonesia has mention both requirements in the OHS Policy, but not yet made into a specific document and reviewed periodically.

Responsibility and authority to act related to OHSMS is defined in those Principal Regulation and in the OHSMS Guideline of Universitas Indonesia. Participation and consultation with workers is done by creating several 
committees in the fields of construction, transportation, canteen, contractor, etc. Each committee consists of 4-10 people from employee and lecturer representatives who have expertise in each of the field. The committee's involvement involved responding to OHS issues related to their respective fields and providing recommendations for improving OHSMS performance in the Universitas Indonesia. The committee's recommendations are given to UPT K3L verbally or in writing, but not yet documented properly.

TABLE I. OHSMS REQUIREMENTS AND COMPLIANCE

\begin{tabular}{|c|c|c|c|}
\hline & OHSMS Requirements & $\begin{array}{c}\text { Implemented but not yet } \\
\text { documented }\end{array}$ & $\begin{array}{c}\text { Implemented and } \\
\text { documented }\end{array}$ \\
\hline \multirow{6}{*}{ OHS Policy } & Understanding of the organization and its context & $\mathrm{v}$ & \\
\hline & $\begin{array}{l}\text { Understanding the needs and expectations of workers and other } \\
\text { interested parties }\end{array}$ & $\mathrm{v}$ & \\
\hline & Establish OHSMS Scope & & $\mathrm{v}$ \\
\hline & Establish OHS Policy & & $\mathrm{V}$ \\
\hline & Responsibility and Authority to Act & & $\mathrm{V}$ \\
\hline & Participation and Consultation with Workers & $\mathrm{v}$ & \\
\hline \multirow{4}{*}{ OHS Planning } & Hazard Identification, Risk Assessment and Determining Control & & $\mathrm{v}$ \\
\hline & Determining legal and other requirements & & $\mathrm{V}$ \\
\hline & Establish OHS objectives & & $\mathrm{v}$ \\
\hline & Establish OHSMS guidelines & & $\mathrm{v}$ \\
\hline \multirow{5}{*}{ OHS Operation } & Provide resource and improving personnel competence & & $\mathrm{v}$ \\
\hline & $\begin{array}{l}\text { Establish work permit system and provide personal protective } \\
\text { equipment }\end{array}$ & & $\mathrm{v}$ \\
\hline & OHS review and assessment for contractor & & $\mathrm{v}$ \\
\hline & OHSMS communication and documentation & & $\mathrm{v}$ \\
\hline & Emergency preparedness and response & & $\mathrm{V}$ \\
\hline \multirow{3}{*}{ OHS Monitoring } & OHS performance measurement, monitoring and evaluation & & $\mathrm{v}$ \\
\hline & Internal Audit & & $\mathrm{v}$ \\
\hline & Management Review & & $\mathrm{V}$ \\
\hline \multirow{2}{*}{$\begin{array}{c}\text { OHS } \\
\text { Improvement }\end{array}$} & Managing Incidents, non-conformities, and corrective actions & & $\mathrm{V}$ \\
\hline & Continuous Improvement & & $\mathrm{v}$ \\
\hline
\end{tabular}

OHS planning at the Universitas Indonesia is based on three levels as in figure 1 . UPT K3L is a functional unit that has the main task of managing safety and emergency conditions that occur at Universitas Indonesia, and providing support and advice to various activities at the UI in a safe, healthy and environmentally friendly manner. UPT K3L also establish an OHSMS guidelines for Universitas Indonesia and being publicly distributed through their website, which is https://k31.ui.ac.id/.

The hazard identification, assessment and risk control processes are carried out in accordance with their respective levels. Aspects that have been considered in the hazard identification process are: (1) Routine and non-routine activities, (2) Activities of all personnel who have access to the workplace, (3) Human behavior, abilities, and other human factors, (4) Infrastructure, equipment and materials in the workplace, and (5) Dangers arising from and outside the workplace. Risk control are determined based on risk assessment. The risk control consists of elimination, substitution, engineering \& administrative controls, and Personal Protective Equipment (PPE).

\section{OHS Operation}

Resource and personnel competence regarding health and safety are required to implement OHSMS. Every year UPT $\mathrm{K} 3 \mathrm{~L}$ provide several training such as general OHS training, first aid training, emergency response training and simulation, fire extinguisher training, electrical safety, construction safety, etc. Training is intended for all of OHSE Officer and also students of Universitas Indonesia.

Universitas Indonesia has been establish a work permit system for various activities that have potential hazards, including student activities and contractor activities. Work permit submitted to UPT K3L by using the provided form. Work permit is done by identifying: (1) types of hazards at the work site or activity, (2) risk control that needs to be done, (3) required PPE, and (4) various safety measures before work begins. Contractor typically has various potential hazard regarding of their activities, such as building construction project or maintenance work. Universitas Indonesia has establish guidelines for implementation of contractor safety management, to review and assess the safety aspect for each contractor works. Contractor must meet the specified OHS requirements and provide the contractor's OHS plan for a particular project.

Communication and documentation procedures are establish to ensure that the latest OHS information is communicated to all parties, both internal and external UI. The dissemination of OHS information is carried out through information media carried out by UI, among others through notice boards, HSE meetings, letters, training, contracts with external parties, and other information media.

The level of emergencies at the University of Indonesia is divided based on the size of the emergency that occurs, that is: (1) Local emergency situations, which are situations that can be completely resolved by emergency response team 
personnel at work units and do not require additional power, (2) Situation limited emergency, which is a situation that occurs in one / several work units in one area (faculties / public facilities) and may require the help of additional resources, and (3) a large emergency situation, an emergency that can spread beyond the limit of one work unit or even the UI campus boundaries, and need the help of resources from authorities outside the UI, such as the police, fire department, local government, and others. Various types of emergencies at UI include: (1) Fire, (2) Falling Trees, (3) Medical Emergency, (4) Laboratory Incidents, (5) Earthquakes, (6) Traffic Accidents, and (7) Drowned person. Emergency response teams and emergency guidelines have been provided to handle those various emergencies condition.

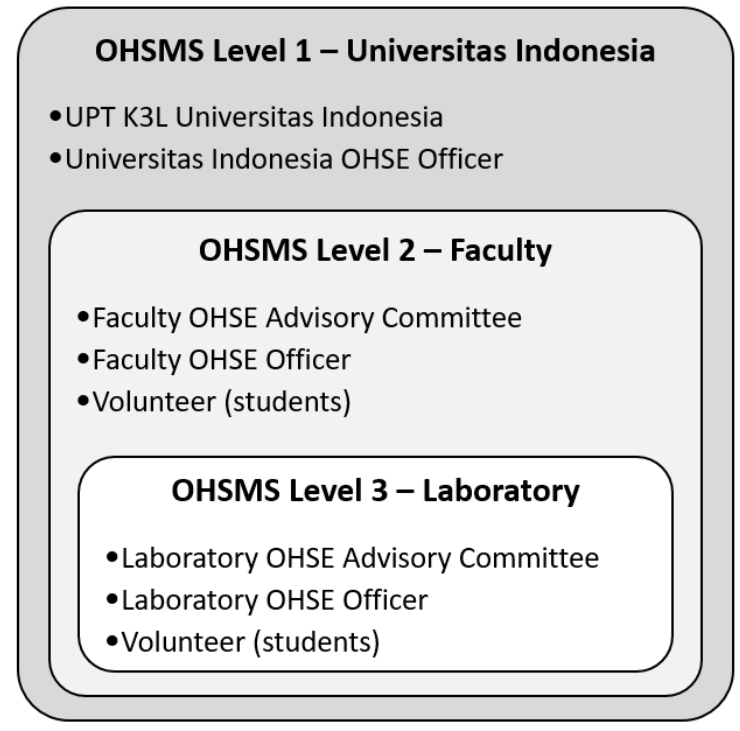

Fig. 1. Occupational Health and Safety Management System (OHSMS) planning in Universitas Indonesia

\section{OHS Monitoring and Continuous Improvement}

Universitas Indonesia carried out routine inspection activities consisting of two types, namely: (1) General Inspections, in the form of building or environmental inspections, and (2) Special Inspections, in the form of inspections of work equipment, work facilities, or certain emergency conditions. Monitoring the work environment includes physical, chemical and biological factors. UPT K3L has the role of setting the inspection schedule and appointing personnel to become Inspectors. The inspection will involve the campus community to provide input and relevant information related to ongoing inspection activities.

Internal audits have been conducted with the frequency of audits determined based on the results of previous audits, but conducted at least once a year. The status of findings in an audit carried out can be either major or minor findings. Corrective action must be taken immediately. For major findings the limit is 1 month, and for minor findings the limit is 3 months. The results of the internal audit and inspection become one of the agendas discussed in the management review meeting to ensure continued suitability and effectiveness in achieving OHS policies and objectives.

Universitas Indonesia has compiled procedures for reporting and investigating incidents, as well as procedures for corrective and preventive actions, as guidelines in managing incidents that occur at UI. The severity of incidents used in UI is divided into three types, that is: (1) minor incident, if it causes a person to be slightly injured or can be treated with first aid or the victim can resume his activities within $1 \times 24$ hours, (2) Serious incident, if it causes a person to be seriously injured, or get medical care, and / or hospitalization, and (3) Fatal incidents or fatalities, are incidents that result in someone experiencing permanent disability or resulting in loss of life. At the Universitas Indonesia, a variety of incidents occur each year, which has been recorded and implemented the corrective actions needed. Incidents that occur include vehicle accidents (motorcycle, car, and bicycle), fallen trees, fires, occupational illness, person drowning, earthquakes, etc.

Universitas Indonesia makes continuous improvements based on the results of internal audits, inspections, recommendations from workers, and based on incidents that have occurred before. Continuous improvement efforts are also made by creating competition between faculties in creating new innovations for the implementation of OHSMS in UI. First example of a continuous improvement effort that has been implemented is by providing an incident reporting service in the smartphone application-based UI called "UI Panic Button". This application can be downloaded publicly and serves to report incidents in the UI campus that will be received by the Emergency Response Team from the UPT $\mathrm{K} 3 \mathrm{~L}$, so that incidents can be handled quickly. The second example of innovation is to use drones as an additional tool for conducting inspections. Through the use of drones, the implementation of Inspections can be done from a different and broader perspective.

\section{CONCLUSION}

Based on the results and discussions related to the implementation of the Occupational Health and Safety Management System (OHSMS) at Universitas Indonesia and its compliance towards to Government Regulation of the Republic of Indonesia Number 50 of 2012 regarding the application of OHSMS and ISO 45001:2018 as international standards on OHSMS, the conclusions are as follows:

- Universitas Indonesia has been implemented OHSMS through three levels of implementation, and being managed by UPT K3L as the functional unit that has the main task of managing safety and emergency conditions that occur at Universitas Indonesia.

- There are 20 main requirements and divided into five category regarding to OHSMS, that is derived from the Government Regulation of the Republic of Indonesia Number 50 of 2012 regarding the application of OHSMS and ISO 45001:2018 as OHSMS international standards.

- Implementation of OHSMS at Universitas Indonesia shows that from 20 main requirements that have been made, 17 requirements have been implemented and documented and 3 requirements have been implemented but not yet documented.

The recommendations given are to improve documentation management throughout OHSMS implementation, while maintaining various innovations for OHSMS implementation in Universitas Indonesia. Further 
studies could be conducted to improve efficiency of documentation management, for example using web-based platform to create and store several information regarding OHSMS implementation.

\section{ACKNOWLEDGMENT}

The author would like to thank the financial support provided by the Universitas Indonesia through PUTI Doctor of the Fiscal Year 2020 with the contract number: NKB-689/ UN2.RST / HKP.05.00 / 2020 managed by the Directorate of Research and Community Engagement (DRPM) Universitas Indonesia.

\section{REFERENCES}

[1] Arifin K, Ahmad S, Aiyub K, Awang A, Mohamad L Z, Aziz A, Mamat S A and Razman M R, Health and safety management in university's student residential college: An overview of students' perception and awareness Res. J. Appl. Sci. 5 165-71, 2010.

[2] Li Y and Guldenmund F W, Safety management systems: A broad overview of the literature Saf. Sci. 103 94-123, 2018.

[3] Guldenmund F W, Understanding and exploring safety culture Res. Agenda Risk Des. Anno 2005. 20 Years Chair Saf. Sci. TU Delft 1985-2005 1466-80, 2010.

[4] Primadianto D, Putri S K and Alifen R S, Pengaruh Tindakan Tidak Aman ( Unsafe Act ) Dan Kondisi Tidak Aman ( Unsafe Condition )
Terhadap Kecelakaan Kerja Konstruksi Univ. Kristen Petra 7 77-84, 2018.

[5] Van Noorden R 2011 A death in the lab Nature 472 270-1

[6] Tymvios $\mathrm{N}$ and Gambatese $\mathrm{J}$ A, Perceptions about design for construction worker safety: Viewpoints from contractors, designers, and university facility owners J. Constr. Eng. Manag. 142 1-11, 2016.

[7] Yanar B, Lay M and Smith P M, The Interplay Between Supervisor Safety Support and Occupational Health and Safety Vulnerability on Work Injury Saf. Health Work 10 172-9, 2019.

[8] Kurniawidjaja L M 2015 Teori dan Aplikasi Kesehatan Kerja (Depok: Penerbit Universitas Indonesia)

[9] Government Regulation of the Republic of Indonesia 2012 Regulation No. 50/2012 regarding the application of OHSMS

[10] International Organization for Standardization 2018 ISO 45001:2018 - Occupational health and safety management systems

[11] Backlund A 2000 The definition of system Kybernetes 29 444-51

[12] Moen R, Foundation and History of the PDSA Cycle Assoc. 2009. Process Improv. 2-10

[13] Mangkunegara A and Anwar A 2011 Manajemen Sumber Daya Manusia (Bandung: PT. Remaja Rosdakarya Offset)

[14] Haerani R, Pengaruh Keselamatan dan Kesehatan Kerja terhadap Kinerja Karyawan J. Adm. Bisnis 15 1-7, 2014.

[15] Saldaña M, Herrero S, del Campo $M$ and Ritzel D, Assessing definitions and concepts within the safety profession Int. Electron. J. Health Educ. 6 1-9, 2003. 